\title{
EVALUATION OF THE COMPARATIVE INFLUENCE OF MAGNESIUM SULFATE SINGLE AND COMBINATION WITH RITODRINE HYDROCHLORIDE IN THE PREVENTION OF PRETERM DELIVERY
}

\author{
AVALIAÇÃO DA INFLUENNCIA COMPARATIVA DO SULFATO DE \\ MAGNÉSIO ÚNICO E COMBINAÇÃO COM CLORIDRATO DE RITODRINA NA \\ PREVENÇÃO DO PARTO PREMATURO
}

\author{
Xu SHUIFANG ${ }^{1}$; Zhang FENGYING ${ }^{1}$; He YUHUA, Lv XIYUN ${ }^{1}$; Tian JINFANG $^{1}$; Qi YI ${ }^{1}$; \\ Xu FENGYING ${ }^{*}$ \\ 1. Department of Gynaecology and Obstetrics Tinglin Hospital of Jinshan District, Shanghai, China. \\ "Correspondence author: Xu FENGYING
}

\begin{abstract}
This project was designed to explore the effects of ritodrine hydrochloride combined with magnesium sulfate in the prevention of preterm delivery of patients with threatened premature birth. 128 cases of threatened premature birth were randomly divided into two groups according to the number table method. The control group was treated with magnesium sulfate, while the study group was treated with ritodrine hydrochloride combined with magnesium sulfate. The data $(p>0.05)$ was analyzed using SPSS 18.0 and was subjected to Chi-square and t-test. The onset time and prolonged gestation time of the study group were shorter than those of the control group $(p<0.05)$. There was no difference in the incidence of myocardial ischemia between the study group and the control group $(p>0.05)$. The heart rate per minute of the study group was higher than that of the control group $(p<0.05)$. There was no difference in blood pressure between the study group and the control group. Nevertheless, the neurological function, pregnancy outcome, and neonatal status of the group were better than those of the control group $(p<0.05)$.
\end{abstract}

KEYWORDS: Ritodrine. Magnesium sulfate. Comparison. Preterm pregnancy.

\section{INTRODUCTION}

It is well established that preterm birth (PTB) is an important public health concern in both developed and developing countries. A PTB is defined as a delivery before 37 weeks of gestation due to the onset of preterm labor. The incidence of PTB may vary across the globe and may depend on environmental factors and socioeconomic settings. Recently, the World Health Organization (WHO) projected that each year approximately 15 million babies are born preterm and this number is increasing. PTB complications are the main cause of death among children below 5 years of age and were responsible for nearly 1 million deaths in 2013. Data from 184 countries suggested that the PTB rate ranges from $5 \%$ to $18 \%$ in different parts of the world (WHO, 2016). The increase in the PTB rate can be linked to several factors. Most PTBs occur spontaneously; however, a proportion of such births is due to very early onset of labor and cesarean birth, either due to medical or nonmedical reasons. Common causes of PTB include multiple fetuses, intrauterine infections, hormonal deregulations, chronic conditions, i.e., diabetes and high blood pressure, and genetics. A better understanding of the mechanistic underpinnings for PTB will certainly lead to the development of better therapeutic options to prevent this dreaded pregnancy malady (KUMAR; SHARMA; THAKER, 2017). Recently, pregnant women are more and more likely to have threatened premature delivery in the middle and late stages of pregnancy due to the influence resulted from environmental pollution and life stress (ZHANG, 2017). Low placenta, cervical insufficiency and the weight and height of the pregnant woman may cause threatened preterm birth. At present, the premature delivery can be prevented for pregnant women with threatened premature birth by proper medication (MERCADANTE; RIBEIRO; RISCO, 2016). Commonly used drugs for the treatment of threatened preterm labor include ritodrine hydrochloride, magnesium sulfate, etc., but these two drugs have a certain inhibitory effect on the neurological function of pregnant women when used alone (XU; REN; ZHAI, 2016). Therefore, in order to find a better therapeutic regimen, the combination of ritodrine hydrochloride and magnesium sulfate was adopted to intervene in this study. The study 
was carried out on the premise of obtaining the approval of the hospital ethics committee. Magnesium sulfate is one of the drugs that has been used to try to stop the uterus contracting in women who go into labor soon. Magnesium sulfate, or mag for short, is used in pregnancy to prevent seizures due to worsening preeclampsia to slow or stop preterm labor and to prevent injuries to a preterm baby's brain.

Magnesium sulfate is given as an intravenous infusion or intramuscular injection in the hospital for over 12 to 48 hours. It relaxes smooth muscle tissues, which helps to prevent seizures and slow uterine contractions.

\section{MATERIAL AND METHODS}

\section{General data}

128 cases of patients with threatened premature delivery admitted to Tinglin Hospital were randomly divided into two groups according to the digital table method, with 64 cases in each group. The sample size was collected using the sample random techniques. The pregnant women in the control group were 24-38 years old, with an average age of $(32.2 \pm 1.2)$ years, $28-35$ weeks of gestational weeks, and an average gestational age of (29.4 \pm 2.1$)$ weeks. Similarly, pregnant women in the study group were $25-38$ years old, with an average age of (32.4 \pm 1.3$)$ years, $28-34$ weeks of gestation, and an average gestational age (28.6 \pm 2.3$)$ weeks. There were no significant differences in age, gestational age, heart rate, blood pressure, emotional state, series addition and subtraction, visual retention, and curvilinear anastomosis between the two groups of patients $(p>0.05)$.

\section{Inclusion Criteria:}

1. Pregnant women who developed regular uterine contractions, about 1 time every 10 minutes and each time lasted for more than 30 seconds.

2. Pregnant women with cervical softening.

3. Pregnant women with a singleton pregnancy.

4. Pregnant women who were informed about the content of this study and signed the consent form.

\section{Exclusion Criteria:}

1. Pregnant women with obvious cervical dilatation $\geq 2 \mathrm{~cm}$.

2. Pregnant women with multiple pregnancies.

3. Pregnant women with gestational merger disease or complications.

4. Pregnant women with cardiovascular and cerebrovascular diseases.

5. Pregnant women who are not suitable for embryo protection after clinical diagnosis.

6. Pregnant women with physiological contractions.

\section{Study design}

1: The pregnant women in the control group were treated with Magnesium Sulfate.

\section{Specific Method}

Intravenous infusion of magnesium sulfate (Chinese medicine quasi character) was performed. $20 \mathrm{ml}$ of $25 \%$ magnesium sulfate was added to $100 \mathrm{ml}$ of $5 \%$ glucose solution for intravenous drip, and the drip was completed within 30 minutes. Then the dosage of magnesium sulfate was adjusted to $2 \mathrm{~g} / \mathrm{h}$. Moreover, if the uterine contraction disappeared, the dosage was adjusted to $1 \mathrm{~g} / \mathrm{h}$. The drug was stopped after 12 hours of continuous infusion (PAIXÃO; TEIXEIRA; MDCN, 2016).

2: The pregnant women in the study group were treated with ritodrine hydrochloride on the basis of the control group. The therapeutic time duration of ritodrine hydrochloride is used till $37^{\text {th }}$ week of gestation

\section{Specific Method}

The medication of Magnesium Sulfate (Chinese medicine quasi character) was the same as that of the control group. At the same time, ritodrine hydrochloride was administered by intravenous drip. $100 \mathrm{mg}$ ritodrine was added to $500 \mathrm{ml}$ of $5 \%$ glucose solution and the initial instillation dose was controlled at $0.05 \mathrm{mg} / \mathrm{min}$, approximately 5 drops per minute, and then increased once every 10 minutes. The increase was stopped when the dose became between $0.15 \mathrm{mg}$ and $0.35 \mathrm{mg}$. In addition, the infusion was continued for 12 hours after the uterine contraction disappears (TONG; WEI; WANG, 2017; LUO; RAN; ZHANG, 2016; DUAN; LIU, 2016).

\section{Observational Index}

The onset time, prolonged gestation time, as well as the occurrence of myocardial ischemia were observed and recorded in the two groups. The changes in heart rate and blood pressure before and after treatment were recorded in the two groups. The neurological behavioral tests were performed after treatment in both groups and the operations were performed in strict accordance with the requirements of the WHO NCTB. The main test items included emotional state, series addition and subtraction, visual retention, curvilinear anastomosis, and target tracking (CORTES; 
Evaluation of the comparative...

ABRUZZESE; CHELYSHEVA, 2016). Pregnancy outcomes and neonatal status were recorded, including neonatal weight and 1-minute Apgar score. 1min Apgar score (SUN; YE; LI, 2016), mainly contained muscle tension, pulse, frowning action that was, response to stimuli, skin color, breathing, 0-10 points, the higher the score, the better the newborn condition.

\section{Statistical analysis}

The data was analyzed using SPSS 18.0 in which the count data was subjected to the Chisquare test (\%), while the measurement data was performed by t-test $(\mathrm{x} \pm \mathrm{s}) . p<0.05$ indicated a significant difference.

\section{Ethical Consideration}

SHUIFANG, X. et al.

This study was approved by the institutional ethical review board of the, PR China. All the experiments were conducted as per Helsinki's declaration for human volunteers. All subjects gave informed, signed consent to participate in the study by themselves.

\section{RESULTS AND DISCUSSION}

\section{Analysis of Onset Time, Prolonged Gestation Time, and Occurrence of Myocardial Ischemia}

The onset time and prolonged gestation time of the study group were shorter than those of the control group $(p<0.05)$. There was no difference in the incidence of myocardial ischemia between the study group and the control group $(p>0.05)$. Specific details recorded are shown in Table 1.

Table 1. Comparison of onset time, prolonged gestation time and incidence of myocardial ischemia (Cases, $\%, \overline{\mathrm{x}} \pm \mathrm{s})$

\begin{tabular}{lllll}
\hline Groups & Cases & Onset time $(\mathrm{h})$ & $\begin{array}{l}\text { Prolonged gestation } \\
\text { time }\end{array}$ & $\begin{array}{l}\text { Myocardial } \\
\text { ischemia }\end{array}$ \\
\hline Control group & 64 & $5.8 \pm 1.3$ & $28.3 \pm 3.5(\mathrm{~h})$ & $3(4.7)$ \\
\hline Research group & 64 & $2.8 \pm 0.9$ & $21.5 \pm 2.5(\mathrm{~h})$ & $3(4.7)$ \\
\hline $\mathrm{T} / \mathrm{X} 2$ & --- & 15.394 & $11.391(\mathrm{~h})$ & 0.125 \\
\hline$P$ & --- & $<0.05$ & $<0.05(\mathrm{~h})$ & $>0.05$ \\
\hline
\end{tabular}

Analysis of Blood Pressure and Heart Rate

Heart rate per minute in the study group was

higher than that in the control group $(p<0.05)$.

There was no significant difference in blood pressure between the study group and the control group $(p>0.05)$. Specific details were demonstrated in Table 2.

Table 2. Comparison of blood pressure and heart rate $(\mathrm{x} \pm \mathrm{s})$

\begin{tabular}{llllll}
\hline Groups & Time & $\begin{array}{l}\text { Heart Rate (Times / } \\
\text { Min) }\end{array}$ & $\begin{array}{l}\text { Diastolic } \\
\text { Pressure (mmHg) }\end{array}$ & $\begin{array}{l}\text { Blood } \\
\text { Pressure (mmHg) }\end{array}$ \\
\hline Control Group & Before Medication & $84.5 \pm 4.3$ & $68.2 \pm 5.2$ & $101.1 \pm 7.8$ \\
\cline { 2 - 5 } & After Medication & $86.2 \pm 4.9$ & $66.8 \pm 4.5$ & $99.5 \pm 8.7$ \\
\hline Research Group & Before Medication & $82.1 \pm 4.5$ & $65.7 \pm 4.2$ & $103.1 \pm 8.9$ \\
\cline { 2 - 5 } & After Medication & $113 \pm 5.6 \mathrm{a}$ & $64.5 \pm 5.3$ & $99.8 \pm 9.2$ \\
\hline
\end{tabular}

Note: compared with before medication, a $p<0.05$.

The neurological function of the study group was better than that of the control group $(p<0.05)$, as shown in Table 3. 
Table 3. Comparison of neurological status $(\mathrm{x} \pm \mathrm{s})$

\begin{tabular}{|c|c|c|c|c|c|}
\hline Groups & $\begin{array}{l}\text { Neurological } \\
\text { Status }\end{array}$ & Control Group & Research Group & $\mathrm{T}$ & $p$ \\
\hline \multirow{6}{*}{$\begin{array}{l}\text { Emotional } \\
\text { State }\end{array}$} & Tension-Anxiety & $63.4 \pm 13.5$ & $35.1 \pm 15.2$ & 12.341 & $<0.05$ \\
\hline & $\begin{array}{ll}\text { Depression } & - \\
\text { Melancholy } & \end{array}$ & $72.5 \pm 12.5$ & $45.3 \pm 12.5$ & 11.234 & $<0.05$ \\
\hline & Anger - Hostility & $65.8 \pm 21.5$ & $32.8 \pm 16.3$ & 15.671 & $<0.05$ \\
\hline & Powerful - Active & $52.8 \pm 13.2$ & $20.1 \pm 12.8$ & 15.364 & $<0.05$ \\
\hline & Tired-Inert & $62.5 \pm 13.1$ & $38.9 \pm 23.5$ & 15.341 & $<0.05$ \\
\hline & $\begin{array}{ll}\text { Puzzled- } \\
\text { Confused }\end{array}$ & $195.6 \pm 23.4$ & $168.9 \pm 23.5$ & 11.237 & $<0.05$ \\
\hline \multirow{4}{*}{$\begin{array}{l}\text { Series } \\
\text { Addition and } \\
\text { Subtraction }\end{array}$} & $\begin{array}{l}\text { Accurate Number } \\
\text { of Times }\end{array}$ & $101.3 \pm 12.5$ & $134.6 \pm 23.4$ & 13.248 & $<0.05$ \\
\hline & Time Per Request & $24.8 \pm 13.7$ & $15.9 \pm 12.1$ & 13.278 & $<0.05$ \\
\hline & Fastest & $14.5 \pm 11.4$ & $15.3 \pm 12.3$ & 13.347 & $<0.05$ \\
\hline & Slowest & $45.6 \pm 12.6$ & $62.7 \pm 23.5$ & 14.678 & $<0.05$ \\
\hline \multirow{2}{*}{$\begin{array}{l}\text { Visual } \\
\text { Retention }\end{array}$} & Correct Judgment & $22.7 \pm 11.5$ & $35.6 \pm 13.2$ & 11.345 & $<0.05$ \\
\hline & Misinterpretation & $41.5 \pm 12.3$ & $23.2 \pm 9.1$ & 13.271 & $<0.05$ \\
\hline \multirow[t]{4}{*}{$\begin{array}{l}\text { Curvilinear } \\
\text { Anastomosis }\end{array}$} & $\begin{array}{l}\text { Deviation from } \\
\text { Average Distance }\end{array}$ & $65.3 \pm 28.6$ & $45.9 \pm 31.5$ & 11.378 & $<0.05$ \\
\hline & $\begin{array}{l}\text { Number of } \\
\text { Coincidence Points }\end{array}$ & $1215.6 \pm 236.4$ & $2536.5 \pm 435.8$ & 16.345 & $<0.05$ \\
\hline & Minimum Offset & $18.6 \pm 5.8$ & $6.4 \pm 12.5$ & 15.387 & $<0.05$ \\
\hline & Maximum Offset & $89.6 \pm 23.5$ & $63.5 \pm 12.6$ & 14.394 & $<0.05$ \\
\hline \multirow{2}{*}{$\begin{array}{l}\text { Target } \\
\text { Tracking }\end{array}$} & Correct Number & $223.6 \pm 24.1$ & $356.6 \pm 10.2$ & 14.694 & $<0.05$ \\
\hline & Real Quantity & $258.6 \pm 21.5$ & $384.6 \pm 111.3$ & 11.397 & $<0.05$ \\
\hline
\end{tabular}

Analysis of Pregnancy Outcome and Neonatal Condition

Table 4. Comparison of pregnancy outcome and neonatal condition (Cases, $\%, \overline{\mathrm{x}} \pm \mathrm{s}$ )

\begin{tabular}{|c|c|c|c|c|c|c|}
\hline \multirow[t]{2}{*}{ Groups } & \multirow[t]{2}{*}{ Cases } & \multicolumn{2}{|c|}{ Pregnancy outcome } & \multicolumn{3}{|l|}{ Neonatal condition } \\
\hline & & $\begin{array}{l}\text { Successful } \\
\text { fetus } \\
\text { protection }\end{array}$ & $\begin{array}{l}\text { Failure of } \\
\text { fetus } \\
\text { protection }\end{array}$ & $\begin{array}{l}\text { Neonatal birth } \\
\text { weight }\end{array}$ & $\operatorname{lmin}_{\text {(points) }}$ Apgar & score \\
\hline Control group & 64 & $55(85.9)$ & $9(14.1)$ & $2.9 \pm 0.1$ & $9.7 \pm 0.8$ & \\
\hline $\begin{array}{l}\text { Research } \\
\text { group }\end{array}$ & 64 & $63(98.4)$ & $1(1.6)$ & $2.2 \pm 0.1$ & $8.4 \pm 0.6$ & \\
\hline $\mathrm{T} / \mathrm{X} 2$ & --- & 4.645 & 5.642 & 11.354 & 14.457 & \\
\hline $\mathrm{P}$ & $\begin{array}{ll}-- \\
--\end{array}$ & $<0.05$ & $<0.05$ & $<0.05$ & $<0.05$ & \\
\hline
\end{tabular}

Premature delivery is defined as the pregnancy period of a pregnant woman that has exceeded 28 weeks but has not yet reached 37 weeks of delivery. The incidence of this condition ranges from $3 \%$ to $16 \%$. It was showed in the previous data that $10 \%$ of premature babies die at the neonatal stage and $75 \%$ of premature babies, even if they may survive, often suffer from intellectual deficits and neurological problems (CORTES; ABRUZZESE; CHELYSHEVA, 2016). In recent years, the group of older mothers is
The pregnancy outcome and neonatal condition in the study group were better than those in the control group $(p<0.05)$, as shown in Table 4 . 
Evaluation of the comparative...

allylestradiol does not increase the incidence of muscle block in newborns at all and it can reduce the risk of threatened abortion. Moreover, it can also lengthen the pregnant women's gestational period, greatly reduce the time needed for pregnant women to be hospitalized and reduce the adverse reactions of pregnant women to the drugs (SLIWA; VANHAGEN; BUDTS, 2016). The data from this study showed that the pregnant women in the study group had a series of neurobehavioral functions in pregnant women after treatment with ritodrine hydrochloride combined with allylestrenol, including serial addition and subtraction, emotional state, curve anastomosis, visual retention as well as target tracking which were all significantly better than those in the control group. A series of neurobehavioral tests accurately expressed the neurological impairment of medication in pregnant women with threatened preterm birth and played an important role in the neurobehavioral changes caused by the evaluation of medication (XIE; MA, 2017). In this study, the total effective rate of the study group $(94.0 \%)$ was significantly better than that of the control group. Meanwhile, all indicators in the study group were obviously superior to those of the control group.

The combination of ritodrine hydrochloride with allylestrenol can evidently attenuate a range of neurological impairments caused by single medication in threatened preterm labor (LI; ZHANG; WANG, 2016). It has been exhibited in the previous studies that the adverse effects resulted from the single medication can be reduced through the combined therapy with ritodrine hydrochloride and allylestradiol, thereby relieving a series of concomitant neurological impairments to pregnant women (BOYLE; THORSTENSEN; MOURATH, 2016). In addition, serum NSE is also one of the
SHUIFANG, X. et al.

basic indicators for testing whether a pregnant woman has brain damage. It was concluded that the treatment of ritodrine hydrochloride combined with allylestradiol would not exacerbate the severity of brain damage caused by drugs. At the same time, the utilization of ritodrine hydrochloride combined with allylestradiol is very stable and effective, and it can also increase the efficacy between the drugs, thereby relieving the adverse effects of the drug on the nervous system of pregnant women (DAI; XU; MA, 2016). Glial cells in the system of the central nervous system can synthesize and produce S-100 $\beta$ protein, and completely exert biological effects with its own active form. Ritodrine hydrochloride is a highly selective $\beta 2$-type adrenaline, which is also a receptor that can control uterine contractions to a great extent and has a very effective effect on the treatment of threatened abortion in pregnant women, but if used too much, it can cause tremors and very rare gait instability as well as a series of systematic adverse effects on the nervous system (WANG; XIAO, 2016). In this study, the $\beta-H C G$ and $P$ levels in the study group were significantly higher than those in the control group. The incidence of adverse reactions in pregnant women in the study group was $21.2 \%$, which was dramatically lower than that in the control group.

\section{CONCLUSION}

To sum up, the utilization of ritodrine hydrochloride combined with allylestradiol was clinically significant in the process of treating threatened premature pregnant women. Furthermore, it did not increase the risk of treatment of pregnant women, and the effect was ideal, so the clinical application needs to be further promoted.

RESUMO: Este projeto foi desenvolvido para explorar os efeitos do cloridrato de ritodrina combinado com sulfato de magnésio na prevenção do parto prematuro de pacientes com risco de nascimento prematuro. 128 casos de nascimento prematuro ameaçado foram divididos aleatoriamente em dois grupos, de acordo com o método da tabela numérica. O grupo de controle foi tratado com sulfato de magnésio, enquanto o grupo de estudo foi tratado com cloridrato de ritodrina combinado com sulfato de magnésio. Os dados $(p>0,05)$ foram analisados pelo SPSS 18.0 e submetidos ao teste do qui-quadrado e ao teste t. O tempo de início e o tempo prolongado de gestação do grupo de estudo foram menores que os do grupo de controle $(p<0,05)$. Não houve diferença na incidência de isquemia miocárdica entre o grupo de estudo e o grupo de controle $(\mathrm{p}>0,05)$. A frequência cardíaca por minuto do grupo de estudo foi superior à do grupo controle $(p<0,05)$. Não houve diferença na pressão arterial entre o grupo de estudo e o grupo de controle. No entanto, a função neurológica, o resultado da gravidez e o status neonatal do grupo foram melhores do que os do grupo de controle $(p<0,05)$.

PALAVRAS-CHAVE: Ritodrina. Sulfato de magnésio. Comparação. Gravidez pré-termo. 


\section{REFERENCES}

BOYLE, V. T.; THORSTENSEN, E. B.; MOURATH, D. The relationship between 25-hydroxyvitamin D concentration in early pregnancy and pregnancy outcomes in a large, prospective cohort. British Journal of Nutrition,United kingdom, v 116, n. 828, p. 1409-1415, 2016.. https://doi.org/10.1017/S0007114516003202

CORTES, J. E.; ABRUZZESE, E.; CHELYSHEVA, E. The impact of dasatinib onpregnancy outcomes. American Journal of Hematology, united state, v. 3, n. 90, p. 1111-15, 2016, https: / doi: 10.1002/ajh.24186

DAI, W.; XU, Y.; MA, X. Regulatory effects of low-dose low-molecular-weight heparin combined with magnesium sulfate on serum and placental disease-related molecules in severe preeclampsia. Chinese Journal of Integrative Medicine ,China, v, 10, n. 26, p. 30-33, 2016. https: /doi: 10.3389/fnins.2016.00561

DUAN, T.; LIU, M. Discussion on two hot issues of premature delivery. Chinese Journal of Practical Gynecology and Obstetrics, China, v. 8, n. 33, p. 36-39,2016.

KUMAR, S.; SHARMA, S.; THAKER, R. Occupational, Environmental, and Lifestyle Factors and their Contribution to Preterm Birth - An Overview. Indian Journal of Occupational and Environmental Medicine, India, v. 1, n. 21, p. 9-17, 2017. https: /doi: 10.4103/ijoem.IJOEM_155_16.

LI, J.; ZHANG, W.; WANG, X. Effect of magnesium sulfate on the expression of matrix metalloproteinase-9 and aquaporin-9 in placenta of patients with gestational hypertension. Chinese Medical Journal, China, v. 30, n. 96, p. 2421-23, 2016. https:/DOI: 10.3760/cma.j.issn.0376-2491.2016.30.011.

LUO, X.; RAN, L.; ZHANG, Y. Clinical efficacy of atroxiban and ritodrine in the treatment of late-term abortion and premature delivery of twins. Residency-Obstetrics \& Gynaecology,United kingdom, v. 3, n. 25, p. 455-57, 2016.

MERCADANTE, P. M.; RIBEIRO, E. S.; RISCO, C. Associations between pregnancy-associated glycoproteins and pregnancy outcomes, milk yield, parity, and clinical diseases in high-producing dairy cows. Journal of Periodontal \& Implant Science,South Korea, n. 3,v. 99, p. 3031-40,2016. https: /doi: 10.3168/jds.2014-8974. Epub 2015 Feb 7.

PAIXÃ£, O. E. S.; TEIXEIRA, M. G.; MDCN, C. Dengue during pregnancy and adverse fetal outcomes: a systematic review and meta-analysis. The Lancet Infectious Diseases, United Kingdom, v. 6, n. 16, p. 857-65, 2016. https: /doi: 10.1016/S1473-3099(16)00088-8. Epub 2016 Mar 4.

SLIWA, K.; VANHAGEN, I. M.; BUDTS, W. Pulmonary hypertension and pregnancy outcomes: data from the Registry of Pregnancy and Cardiac Disease (ROPAC) of the European Society of Cardiology. European Journal of Heart Failure, United State, v. 7, n. 18, p. 1119-28, 2016. https:/doi: 10.1002/ejhf.594. Epub 2016 Jul 7

SUN, W.; YE, X.; LI, Z. Advances in clinical research of uterine smooth muscle relaxants. Chinese Journal of New Drugs and Clinical Remedies, China, v. 5, n. 24, p. 861-66, 2016. https: / doi: 10.1002/hep.23384

TONG, L.; WEI, X.; WANG, C. Pregnancy outcomes of magnesium sulfate combined with aspirin in patients with pregnancy-induced hypertension. Chinese Journal of Endocrinology and Metabolism, China, v. 2, n. 34, p. 472-72, 2017. https: / doi: 10.3892/etm.2019.7385

WANG, X.; XIAO, J. Observation on the effect of magnesium sulfate combined with labetalol in the treatment of early onset severe preeclampsia, Frontiers in Cardiovascular Medicine, United state, v. 4, n. 56, p. 63-64, 2016. https: / doi: 10.3389/fcvm.2018.00050

WHO, P. B. Updated. Fact sheet Note 363. 2016. Nov, [Last accessed on 2016 Oct 13]. http://www.who.int/media centre/factsheets/fs363/en/ 
XIE, G.; MA, Y. Effect of Labellol on cardiorenal function and pregnancy outcome in patients with moderate to severe pregnancy-induced hypertension. International Journal of Reproduction, Contraception, Obstetrics and Gynecology, India,v.1,n.57,p.74-76, 2017. http://dx.doi.org/10.18203/23201770.ijrcog20174460

XU, Y.; REN, L.; ZHAI, S. Evaluation of the efficacy of ritodrine hydrochloride combined with allylestradiol in the treatment of threatened preterm labor. Obstetrics and Gynaecology Cases. India, v. 2,n. 25,p. 849-51. https: / DOI: 10.1002/pds.1317

ZHANG, Y. Effect of magnesium sulfate combined with ritodrine hydrochloride on premature rupture of membranes. International Journal of Gynecology \& Obstetrics. United kingdom, v.4, n. 56, p. 44-46, 2017. 